\title{
Efectos independientes del poder doméstico de la esposa y los valores igualitarios del cónyuge sobre el deseo fecundatorio y el uso de anticonceptivos
}

Independent effects of wife's domestic power and husband's egalitarian beliefs on fertility desire and contraceptive use

FEDERICO R. LEÓN 1

Partner, León \& Bustamante Consultores, Lima-Peru

(RECIBIDO 05/11/2013, AcEPTADo 24/03/2014)

\begin{abstract}
RESUMEN
¿El poder decisional doméstico de la esposa y las creencias igualitarias del cónyuge concernientes al rol de la mujer determinan independientemente el uso de anticonceptivos? ¿Determinan el deseo fecundatorio de manera similar? ¿Cuál es la función de la edad, la educación y el trabajo en estos procesos? Varias bases de datos del tipo recodificación de parejas de la Encuesta Demográfica y de Salud fueron analizadas con foco en mujeres no embarazadas que viven con una pareja sexual y la pareja. Las bases de datos comprendían muestras rurales y urbanas de India $(\mathrm{N}=23,342)$, Indonesia $(\mathrm{N}=7,219)$ y Nigeria $(\mathrm{N}=$ $7,062)$, así como una muestra rural de Etiopía $(\mathrm{N}=2,531)$. Se halló que el deseo fecundatorio de la esposa era menor cuanto mayor era el igualitarismo del cónyuge en ámbitos urbanos y cuanto mayor era el poder de ella en ámbitos rurales. Independientemente del ámbito, el uso de anticonceptivos aumentaba cuando el igualitarismo del cónyuge y el poder de la mujer eran mayores, y tanto las creencias como el poder presentaron mayores efectos sobre el uso de anticonceptivos que sobre el deseo fecundatorio. Al removerse la varianza asociada con edad, educación y trabajo de los predictores, se observó una reducción de los odds-ratios de menos del 50 por ciento y de manera semejante para poder y creencias. Los programas pueden necesitar dirigirse a las parejas para maximizar el impacto de intervenciones orientadas a incrementar el uso de anticonceptivos a través del empoderamiento de la mujer.
\end{abstract}

Palabras clave: poder doméstico de la mujer, creencias igualitarias de los hombres, deseo fecundatorio, uso de anticonceptivos

\begin{abstract}
Do wives' household decision-making power and husbands' egalitarian beliefs concerning women's roles independently determine contraceptive use? Do they determine fertility desire in analogous ways? What is the function of age, education, and work in these processes?
\end{abstract}

1 Psicólogo investigador del Partner, León \& Bustamante Consultores, Lima-Peru. E-maill: federicorleone@gmail.com 
EFECTOS INDEPENDIENTES DEL PODER DOMÉSTICO DE LA ESPOSA Y LOS VALORES IGUALITARIOS DEL CÓNYUGE...

Analyses of Demographic and Health Surveys' Couple Recode data sets targeted nonpregnant women living with a sexual partner and the partner. The analyses encompassed rural and urban samples from India $(\mathrm{N}=23,342)$, Indonesia $(\mathrm{N}=7,219)$, and Nigeria $(\mathrm{N}$ $=7,062)$, and a rural sample from Ethiopia $(\mathrm{N}=2,531)$. Wife's fertility desire decreased as husband's egalitarianism in urban settings and wife's power in rural areas increased. Regardless of setting, contraceptive use increased as husband's egalitarianism and wife's power increased, and beliefs and power presented greater effects on contraceptive use than on fertility desire. Removal of age, education, and work variance from the predictors reduced the odds-ratios by less than 50 per cent and similarly for power and beliefs. Programs may need to target couples to maximize the impact of interventions to enhance contraceptive use via gender empowerment.

Keywords: women's domestic power, men's egalitarian beliefs, fertility desire, contraceptive use

\section{INTRODUCCIÓN}

Considerable effort is applied to explaining the adoption of contraception by individuals and couples. One of the lines of research has focused on the influence exerted by the different levels of power wielded by men and women as a result of their gender roles in society (Blanc 2001). Since wives and husbands often disagree in their fertility desires and attitudes toward contraception (Bankole \& Singh 1998; Becker 1996; Biddlecom, Casterline, \& Perez 1996; Gebreselassie \& Mishra 2011; Mason \& Smith 2000; Ngom 1997; Singh \& Becker 2012), women's reproductive behaviour frequently expresses gender power inequalities. Thus, the likelihood of a woman using family planning may be determined more by her husband's than by her own fertility preferences (Bankole 1995; Bongaarts \& Bruce 1995; Casterline, Perez, \& Biddlecom 1997; Dodoo 1998; Ezeh 1993; Kimuna \& Adamchak 2001; Wolff, Blanc, \& Ssekamatte-Ssebiliba 2000). Gender power differentials are observed in the type of contraceptive method chosen as well (Biddlecom et al. 1996; Castle, Kane Kunaté, Ulin, \& Martin 1999; Gupta \& Weiss 1993; Speizer, Whittle, \& Carter 2005; Wolff, Blanc, \& SsekamatteSsebiliba 2000). In this context, the amount of individual women's power - i.e., their ability to formulate strategic choices and control resources and decisions that affect important life outcomes (Malhotra, Schuler, \& Boender 2002) - can be expected to have consequences for the adoption of contraception. This expectancy not only owes to the assumption that women need power to overcome husbands' opposition to family planning when they disagree on controlling fertility. It also originates in the realization that women's household decision-making (HDM) power, encompassing freedom of movement, use of economic resources, habit of taking care of their own health, and other behavioural elements, can facilitate access to family planning methods regardless of the couple's level of harmony. There are important differences between societies in women's HDM power (Kishor \& Subaiya 2008), and its impacts on contraceptive use appear to be greater in sub-Saharan Africa than in other world regions (León 2012). 
FEDERICO R. León

\section{Wives' HDM Power and Husbands' Normative Beliefs}

A decade-old review addressed the gender attitudes and behaviours of men and women as two facets of the same issue (Blanc 2001. For instance, women's secret use of contraception (Biddlecom \& Fapohunda 1998; Castle et al., 1999; Green \& Biddlecom 2000; Rutenberg \& CottsWatkins 1997) was interpreted as an expression of their fear of the consequences of transgressing men's norms. Yet, with few exceptions (Blanc \& Wolff 2001; Jejeebhoy 2002; Mason \& Smith 2000; Pulerwitz \& Dworkin 2006) gender research on the use of family planning has followed separate routes for men and women as research targets. The literature addressing the women's HDM power-contraceptive use link has generally ignored men's normative beliefs regarding what women are entitled to do at home and elsewhere. An important part of the research has been concerned with women's self-reported actions in specific household decision areas, either on an item-per-item basis (Chavoshi, Abbasi-Shavazi, \& McDonald 2004; Govindasamy \& Malhotra 1996; Kishor \& Gupta 2009; Moursund \& Kravdal 2003; Schuler, Hashemi, \& Riley 1997; Woldemicael 2009) or considering broader behavioural dimensions such as freedom of movement or economic choice (Jejeebhoy 2002; Mason \& Smith 2000; Moursund \& Kravdal 2003; Roy \& Niranjan 2004; Saleem \&Bobak 2005; Sathar, Callum, \& Jejeebhoy 2001). A better predictor of contraceptive behaviour found in the literature is women's overall HDM power, that is, the general level of HDM power that women sustain across domestic areas (León 2012).

The main focus of men studies, in turn, has been on their normative beliefs concerning couple relationships and the role of women in society; these perceived rules and standards influence social behaviour and vary widely between- and within-countries (Courtenay 2000; Mahalik, Locke, Scott, Greenfield, \& Freitas 2003; Piet-Pelon, Rob, \& Khan 1999; Seguino 2007). The research has sought to understand how men's normative beliefs affect couple dynamics and reproductive conduct and interventions have attempted to convert authoritarian males into egalitarian partners (Peacock \& Levack 2004; Pulerwitz \& Barker 2008; Pulerwitz, Micaelis, Verma, \& Weiss 2010; Shattuck et al. 2011; Verma et al. 2008). Since this work has been oblivious to women's HDM power or excluded women as research subjects, it is not known whether men's egalitarian normative beliefs and women's HDM power are redundant as determinants of contraceptive use or they influence the latter with independence from each other. If women's HDM power fully conformed to men's normative beliefs, taking into account just one of them would suffice to explain contraceptive behaviour in the power perspective. This issue has practical implications: if power and beliefs are not redundant, powerrelated interventions to enhance contraceptive use may need to target both.

\section{Fertility Desires}

By the end of the past century, researchers were addressing the complex relationships that exist between gender power, men's and women's fertility desires, and reproductive behaviour (Mason \& Smith 2000). Most of the research on overall 
HDM that followed targeted contraceptive use as the predicted variable regardless of women's fertility desires, an exception being a study in Oman which focused on met need for contraception (Al Riyami, Afifi, \& Mabry 2004). Contraceptive use and met need pertain to different realms: the former generally indicates the rate of family planning use in a general population of women in reproductive age whereas the latter refers to the rate of use by women with a need for contraception (that is, in risk of pregnancy and not wishing children). Recent Demographic and Health Surveys' (DHS) country reports have shown that women's participation in HDM may be monotonically related only to contraceptive use (e.g., National Population Commission \& ICF Macro 2009), only to met need (e.g., Ghana Statistical Service 2008), or to both (e.g., Instituto Nacional de Estadística et al. 2008). Furthermore, it has been shown that important errors can be committed in the evaluation of program actions aiming to enhance contraceptive use when the assessment ignores women's need for contraception (León, Lundgren, Sinai, \& Jennings 2011). "A woman may not use contraception because she does not need it or because, needing it, something prevents her from using it. Met need discounts risk of pregnancy and fertility desires and provides information exclusively on women's success in overcoming barriers to access to family planning... Fertility desires and risk of pregnancy are confounded with barriers to access when contraceptive use is measured" (León et al. 2011, p. 4). Figure 1 presents a conceptual framework for parsimoniously analysing the relationships between the key variables. By focusing on couples - i.e., virtually setting risk of pregnancy constant -, the Simplest Framework isolates fertility desire as the variable that makes the difference between contraceptive use and met need for contraception. Link 7 is a 3-point sum of wife's (yes $=1$, no $=0$ ) and husband's (yes $=1$, no $=0$ ) fertility desires. The main question implicit in the framework is whether power and beliefs similarly affect fertility desire (links 3, 4, and 5) and contraceptive use (links 2, 6, and 7). Recent studies have addressed elements of the Simplest Framework (DeRose, Dodoo, \& Patil 2002; DeRose, Wu, \& Dodoo 2010; Do \& Kurimoto 2012; Kulczycki 2008; Lee-Rife 2010; Moursund \& Kravdal 2003; Upadhyay \& Karasek 2012), but only tangentially.

\section{Nature of the Constructs}

Overall women's HDM power implies the aggregation of specific power forces in various domestic areas. This construct has been dealt with through three measurement approaches. The DHS (e.g., Institut de Statistiques et d'Études Économiques de Burundi et al. 2010) and others (DeRose \& Ezeh 2010; Hashemi, Schuler, \& Riley 1996; Hogan, Berhanu, \& Hailemariam 1999; León 2012) use a dichotomy of women's participation in HDM that differentiates the woman making the decision herself or jointly with her husband (1 score) from the husband making the decision alone (0 score). An alternative model (Al Riyami et al. 2004; DeRose \& Ezeh 2010; Casique 2003; Feldman et al. 2009; León 2011, 2012; Mumtaz, Slaymaker, \& Salway 2005; Saleem \& Bobak 2005) focuses on the extent of 
FEDERICO R. LEÓN

FIGURE 1. Simplest framework entailing relationships between gender power, fertility desire, and contraceptive use among non-pregnant women.

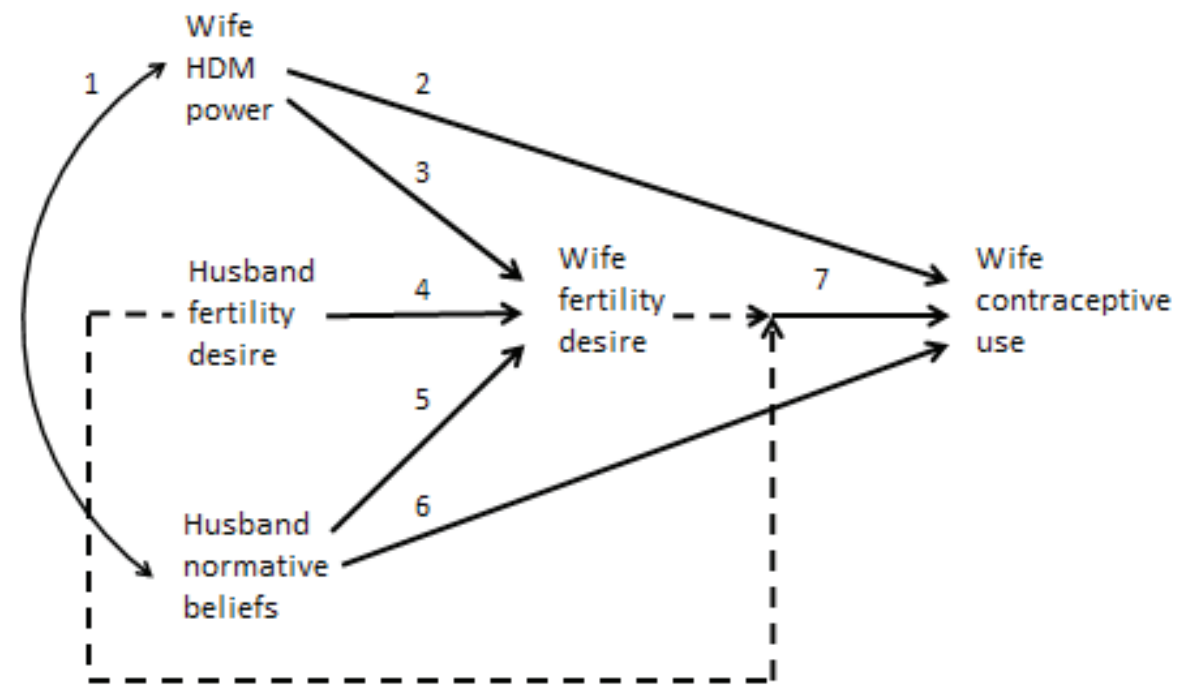

women's control of domestic areas by assigning a larger score to their autonomous decisions (2) than to joint decision-making with the husband (1), the lowest score being given to husband autonomy (0). The third model assumes that the use of family planning is facilitated when the woman is part of an egalitarian couple ready to implement practical arrangements and thus makes decisions jointly with her husband when important issues for the couple are at stake and autonomous decisions in matters of secondary importance. In this case, the assignment of the 2 and 1 scores depends on the importance of the domestic area, the 0 score being assigned to husband autonomy across the board (León 2012). Only two studies have compared the effectiveness of these models in the explanation of contraceptive use (DeRose \& Ezeh 2010; León 2012); the egalitarian HDM model was found more effective than the participation and control models in 30 out of 46 countries (León 2012). It is not known whether men's normative beliefs influence contraceptive use conforming to this model.

Women's age, education, and work for cash are known determinants of women's HDM power (Kishor \& Subaiya 2008). These variables were initially used as proxies for HDM power and have later been used as covariates in the prediction of contraceptive use, showing a superior predictive strength (Al Riyami et al. 2004; Govindasamy \& Malhotra 1996; Hogan et al. 1999) as well as a shared variance with that of women's HDM power (León 2012; Moursund \& Kravdal 2003; Steele, Amin, \& Naved 2001). "As women grow older and meet their fertility 
goals, they become more motivated to use family planning...; education increases the woman's likelihood of learning about family planning methods and how to gain access to them...; by working for cash, women enter into contact with users of contraception and can imitate their behaviour... These are independent effects of age, education, and work for cash on contraceptive use. But as women grow older, they gain experience, and experience may grant them power; education enhances women's ability to control their household environment; and working for cash can affirm women's freedom of movement, whereas the earnings obtained can confer them instrumental and social power. In these cases the path of influence goes from proxy to contraceptive use via women's power. The third source entails effects of women's power on contraceptive use which do not simply reflect the proxies' levels; an amount of power-use covariance is left when the covariance explained by proxies has been partialed out..." (León 2012, p. 3). The proxy-independent women's power component has been attributed to a personality factor, assertiveness (León 2012). Nothing is known about the internal structure of men's normative beliefs.

The study reported in this article was designed to generate evidence of relevance to the three issues: whether wives' household decision-making power and husbands' egalitarian beliefs concerning women's roles independently determine contraceptive use, whether they determine fertility desire in analogous ways, and what is the function of the age, education, and work variables in these processes.

\section{METHODS}

\section{Data}

DHS frequently encompass a matched subset of wives and husbands in each country. This study targeted the two largest Asian countries and two largest African countries which had DHS Couple Recode data sets containing all the needed information (India 2005-06, Indonesia 2007, Nigeria 2008, Ethiopia 2005). According to the Gender-related Development Index (United Nations Development Programme 2012), Indonesia is the most egalitarian and Ethiopia the least egalitarian of the four countries.

Only married or cohabiting women presently living with their husband/partner were considered, to avoid ambiguity in the interpretation of results. Pregnant women were excluded from the analyses. Cases of sterilizations that had occurred two or more years before the survey were excluded, too. When the woman has been sterilized, the relationship between her domestic power and contraceptive use expresses to a considerable extent the paradoxical association between hypothesized effects placed in the remote past (sterilizations performed on average several years earlier) and hypothesized causes placed in the present (current women's power). The urban Ethiopia sample was discarded considering its small size for the regression analyses (effective $\mathrm{N}=151$ ). 
FEDERICO R. LEón

\section{Measures}

- Women's HDM power. DHS generally asks women, "Who usually makes decisions about (health care for yourself) (making major household purchases) (making household purchases for daily needs) (making visits to your family or relatives) - and, less frequently - (children to have)?" Items on decisions on own health care and children to have were absent in some of the women's or men's questionnaires of the selected countries; hence, they were ignored in the analyses. The response options include: Respondent, Husband/partner, Respondent and husband/partner jointly, Someone else, and, infrequently, Respondent and someone else jointly. Someone else information is difficult to interpret, for it may involve a powerful mother-in-law or a powerless relative or domestic servant. Moreover, the husband's normative beliefs items generally do not have response options corresponding to Someone else and Respondent and someone else. Consequently, paired cases presenting such responses for the women's items were discarded. Since the egalitarian power model was adopted in the analyses, the items' frequency distributions were inspected to infer which domestic areas were important and which entailed secondary matters. Some differences were found between countries, but the general trend indicated that joint HDM with the husband prevailed over autonomous wife's decisions for large purchases and visits, whereas the opposite occurred in the case of purchases for daily needs. Consequently, large purchases and visits, likely important areas, required assigning a 0 to "husband", a 1 to "respondent", and a 2 to "respondent and husband" and purchases for daily needs, a less important area, demanded assignment of a 0 to "husband", a 1 to "respondent and husband", and a 2 to "respondent". The sum of item scores produced a 7-point scale.

Husband's normative beliefs. DHS generally asks men, "In a couple, who do you think should have the greater say in each of the following decisions...?" To measure men's normative beliefs concerning women's role, their responses were scored like the women's responses, that is, a 0 was assigned to "husband", a 1 to "wife", and a 2 to "both" in the large purchases and visits areas and a 0 to "husband", a 1 to "both", and a 2 to "wife" in the case of purchases for daily needs.

Contraceptive use. This variable refers to women who were using or not any (modern or traditional) family planning method. The method could be one administered by the partner, such as condoms, but men's reports on contraceptive use were not considered.

Fertility desires. Responses to "Would you like to have (a/another) child or would you prefer not to have (any/more) children?" were scored as follows: No $=0$, Undecided or Yes $=1$. Cases involving infertility or lack of sexual activity were dropped.

Number of living children. This information was obtained from the wife, but was assumed to reflect the fertility of the couple as a whole. 
EFECTOS INDEPENDIENTES DEL PODER DOMÉSTICO DE LA ESPOSA Y LOS VALORES IGUALITARIOS DEL CÓNYUGE...

- Age. DHS calculates age in completed years using present age and date of birth information provided by the respondent.

- Education in single years. This variable considers the respondent's educational level (primary, secondary, tertiary), the highest grade attained at that level, and the number of years taken to reach that grade in the specific country since the respondent's inception in the educational system.

- Work. The respondent who did not work during the last 12 months was differentiated from the one who worked, regardless of how she or he was paid. The mode-of-payment variable was not utilized because it caused important losses of cases.

- Urbanization. This is an urban-rural dichotomy defined according to the demographic-research norms of each country.

- Oversampling. The sampling structure described in each DHS country report was consulted to determine whether each region (or state, or department, or province) was oversampled or not.

\section{Analytic Strategy}

Stratified multistage samples such as DHS's demand of the researcher a strategy to deal with the inflated correlations promoted by clustering and the subset oversampling implied in stratification. Since the first issue's fundamental problem is one of underpowered analysis, it seemed justified to take into account Type I Error probabilities beyond standard significance levels when sample size was $\mathrm{N}<2,000$ $(\mathrm{p}<.10)$. As for oversampling, means for descriptive purposes were obtained utilizing the DHS weighting function, but, following Rutstein and Rojas' (2006) recommendation, weighting was not used in correlation or regression. While there is a wide consensus in using survey weights when estimating population parameters, there is an on-going debate on what to do when the objective is making inferences about model parameters from samples of complex structure (Faiella 2010; Gelman 2007). Thus, the urban and rural raw data were separately analyzed and the other main stratification variable (region, dichotomized into oversampled or not) was included as a fixed-effects variable in the regression models.

Two models were implemented. Model I defined Wife's fertility desire $=$ wife's HDM power + husband's fertility desire + oversampling. The odds-ratio for wife's power in this equation reflects the effects of links 1 and 3 of the Simplest Framework. Regression Model II added husband's egalitarian normative beliefs as a predictor. Hence, under Model II, links 3 and 5 of the Simplest Framework were expressed, respectively, by the odds-ratios for wife's HDM power and husband's normative beliefs, but their common variance (i.e., link 1) was left out of the equation. Similar models were defined for predicting contraceptive use but, 
in this case, the sum of wife's and husband's fertility desires was used instead of the latter alone. To address the proxy-independent component of wife's power and husband's beliefs, the power and beliefs terms were dropped and replaced by residuals: wife's power after the effects of her age, education, and work were partialed out from her power (independently in urban and rural samples) and husband's beliefs after the effects of his age, education, and work were similarly partialed out from his beliefs.

\section{RESULTS}

Table 1 presents means for the study variables, including number of living children.

TABLE 1. Weighted means for study variables and non-weighted internal-consistency coefficients $(\alpha)$ for wife's power and husband's beliefs, per sample ( $W=$ wife, $H=$ husband).

\begin{tabular}{|c|c|c|c|c|c|c|c|c|c|c|c|c|c|c|c|c|}
\hline \multirow[b]{2}{*}{ Samples } & \multirow{2}{*}{$\begin{array}{c}\text { No. } \\
\text { of } \\
\text { Child } \\
\end{array}$} & \multicolumn{2}{|c|}{ Age } & \multicolumn{2}{|c|}{ Education } & \multicolumn{2}{|c|}{$\underline{\text { Work }}$} & \multicolumn{2}{|c|}{$\begin{array}{l}\text { Fertility } \\
\text { Desire }\end{array}$} & \multirow{2}{*}{$\begin{array}{l}\text { Contr. } \\
\frac{\text { Use }}{W}\end{array}$} & \multicolumn{2}{|c|}{$\frac{\text { Wife }}{\text { Power }}$} & \multicolumn{2}{|c|}{$\begin{array}{c}\text { Husband } \\
\text { Beliefs }\end{array}$} & \multicolumn{2}{|c|}{$\underline{\text { Weighted N }}$} \\
\hline & & W & $\mathrm{H}$ & W & $\mathrm{H}$ & W & $\mathrm{H}$ & W & $\mathrm{H}$ & & Mean & A & Mean & $\alpha$ & Min & Max \\
\hline \multicolumn{17}{|l|}{ India } \\
\hline Rural & 2.54 & 29.08 & 34.16 & 3.47 & 5.93 & .455 & .989 & .450 & .392 & .370 & 3.22 & .658 & 3.81 & .371 & 12,818 & 15,200 \\
\hline Urban & 2.09 & 30.20 & 35.89 & 7.62 & 8.99 & .251 & .992 & .391 & .353 & .493 & 3.86 & .605 & 4.26 & .398 & 7,176 & 8,142 \\
\hline \multicolumn{17}{|c|}{ Indonesia } \\
\hline Rural & 2.27 & 33.43 & 38.11 & 6.45 & 6.88 & 649 & .993 & .441 & .502 & .670 & 4.93 & .449 & 4.80 & .318 & 4,120 & 4,240 \\
\hline Urban & 2.28 & 34.44 & 38.68 & 8.84 & 9.41 & .548 & .991 & .414 & .483 & .677 & 4.96 & .429 & 4.98 & .336 & 2,834 & 2,979 \\
\hline \multicolumn{17}{|l|}{ Nigeria } \\
\hline Rural & 3.38 & 30.31 & 39.66 & 3.21 & 4.87 & .679 & .992 & .719 & .783 & .110 & 2.10 & .799 & 1.69 & .483 & 4,879 & 4,918 \\
\hline Urban & 3.20 & 31.67 & 40.42 & 7.88 & 9.15 & .743 & .982 & .658 & .684 & .304 & 2.75 & .773 & 2.20 & .414 & 2,134 & 2,144 \\
\hline \multicolumn{17}{|l|}{ Ethiopia } \\
\hline Rural & 3.75 & 30.23 & 37.73 & 0.55 & 1.72 & .336 & .993 & .608 & .646 & .155 & 3.82 & .416 & 3.97 & .310 & 2,495 & 2,531 \\
\hline
\end{tabular}

Contradicting Gender-related Development Index reports (United Nations Development Programme 2012). Ethiopia showed greater egalitarianism than Nigeria and even India, either considering women's HDM power or men's normative beliefs. The differences between urban and rural settings were smallest in Indonesia. The sums' internal consistencies were high considering the rather small number of items $(n=3)$, yet differed systematically between the two types of summative scales: women reported power behaviours more consistently across domestic areas than men reported normative beliefs concerning women's behaviour in the same areas. This does not indicate that the sum of beliefs is an invalid indicator; it only sets an upper limit for its correlation with other variables. Women's power and men's beliefs correlated more highly in Africa than Asia, the correlations ranging from $r$ $=.09(\mathrm{p}<.000)$ in urban Indonesia through $\mathrm{r}=.25(\mathrm{p}<.000)$ in urban Nigeria.

\section{Fertility desire}

The first set of predictors on Table 2 shows that, under Model I regression, increased wife's power was associated with decreased wife's fertility desire in 
rural India, Nigeria, and Ethiopia and urban India. The significant relationships remained in place, except in rural India, when husband's egalitarian beliefs were included in the regressions (Model II). The pattern of findings suggests that wife's fertility desire was determined only by power associated with beliefs in rural India; by power possibly associated with beliefs, power independent from beliefs, and beliefs independent from power in urban India; by none of the above in rural Indonesia; only by beliefs not associated with power in urban Indonesia and Nigeria; and only by power not associated with beliefs in rural Nigeria and Ethiopia. In sum, wife's power emerged as a stronger determinant of wife's fertility desire in rural settings and husband's egalitarian beliefs in urban settings, while the simultaneous effectiveness of both was unusual. On the other hand, husband's fertility desire was a very

strong and universal covariate of wife's fertility desire, more so in Asia than Africa. Small or under-populated regions in need of oversampling were generally associated with increased wife's fertility desire, with the notable exception of Nigeria.

Removal of age/education/work covariance generally reduced the size of the odds-ratios, but those for wife's power maintained statistical significance in both of the rural African settings, as well as in urban India. Significance was lost by husband's beliefs in all settings. Added in the equations, number of living children (not shown) emerged as a significant and universal negative determinant of wife's fertility desire, but caused virtually no change in the patterns of results of Table 2 .

TABLE 2. Adjusted exponential coefficients from the logistic regression of wife's fertility desire on husband's normative or residual beliefs, wife's HDM or residual power, husband's fertility desire, and oversampling, per predictor set, model, and sample.

\begin{tabular}{|c|c|c|c|c|c|c|c|c|c|c|c|c|}
\hline \multirow{2}{*}{\multicolumn{2}{|c|}{ Samples }} & \multirow[b]{2}{*}{ Model } & \multicolumn{4}{|c|}{ Predictor Set 1} & \multicolumn{6}{|c|}{$\underline{\text { Predictor Set II }}$} \\
\hline & & & $\begin{array}{c}\mathrm{H} \\
\text { Beliefs }\end{array}$ & $\begin{array}{c}\text { W } \\
\text { Power }\end{array}$ & $\begin{array}{c}\mathrm{H} \\
\text { Desire }\end{array}$ & $\begin{array}{c}\text { Over- } \\
\text { sampling }\end{array}$ & $\mathrm{N}$ & $\begin{array}{l}\text { H Res. } \\
\text { Beliefs }\end{array}$ & $\begin{array}{l}\text { W Res. } \\
\text { Power }\end{array}$ & $\begin{array}{c}\mathrm{H} \\
\text { Desire }\end{array}$ & $\begin{array}{c}\text { Over- } \\
\text { sampling }\end{array}$ & $\mathrm{N}$ \\
\hline India & Rural & I & 1.00 & $0.95 * * *$ & $38.16^{* * *}$ & $1.30 * * *$ & 8,416 & 0.99 & 0.98 & $38.33 * * *$ & $1.27 * * *$ & 8,416 \\
\hline Indonesia & Urban & II & $0.92 * * *$ & 0.99 & $45.73 * * *$ & $2.07 * * *$ & 8,272 & 0.98 & 0.99 & $38.42 * * *$ & $1.27 * * *$ & 8,268 \\
\hline Nigeria & Rural & I & 1.03 & $0.93^{* * *}$ & $29.30 * * *$ & $1.41 * * *$ & 8,125 & 1.00 & $0.96^{*}$ & $29.48 * * *$ & $1.39 * * *$ & 8,125 \\
\hline \multirow[t]{11}{*}{ Ethiopia } & Urban & II & $0.89^{* *}$ & $0.96^{*}$ & $27.69 * * *$ & $1.51 * * *$ & 7,993 & 0.95 & 0.97 & $29.77 * * *$ & $1.38 * * *$ & 7,991 \\
\hline & Rural & I & 1.00 & 1.00 & $11.85^{* * *}$ & 1.08 & 3,798 & 0.98 & 0.98 & $11.90 * * *$ & 1.08 & 3,795 \\
\hline & Urban & II & $0.95+$ & 1.01 & $16.37 * * *$ & $1.27 * *$ & 3,704 & 0.98 & 0.99 & $12.31 * * *$ & 1.08 & 3,685 \\
\hline & Rural & I & 1.01 & 1.03 & $17.06 * * *$ & 1.16 & 2,557 & 1.02 & 1.06 & $17.06 * * *$ & 1.16 & 2,557 \\
\hline & & II & & 1.05 & $23.31 * * *$ & $1.28 *$ & 2,496 & & 1.06 & $17.31 * * *$ & 1.18 & 2,494 \\
\hline & & I & & $0.88 * * *$ & $4.34 * * *$ & 1.04 & 4,945 & & $0.89 * * *$ & $4.60 * * *$ & 1.07 & 4,941 \\
\hline & & II & & $0.86^{* * *}$ & $4.30 * * *$ & 0.98 & 4,885 & & $0.90 * * *$ & $4.67 * * *$ & 1.03 & 4,880 \\
\hline & & I & & 0.96 & $7.91 * * *$ & 0.84 & 1,838 & & 0.99 & $8.05 * * *$ & 0.85 & 1,837 \\
\hline & & II & & 0.97 & $8.49^{* * *}$ & $0.77 *$ & 1,823 & & 0.99 & $8.13^{* * *}$ & 0.83 & 1,820 \\
\hline & & I & & $0.88^{* * *}$ & $5.55^{* * *}$ & $1.61 * *$ & 1,772 & & $0.91 * *$ & $5.86^{* * *}$ & $1.46^{* *}$ & 1,772 \\
\hline & & II & & $0.88^{* * *}$ & $5.55^{* * *}$ & $1.62 * *$ & 1,744 & & $0.90 * *$ & $5.89 * * *$ & $1.49 * *$ & 1,744 \\
\hline
\end{tabular}

$+\mathrm{p}<.10, * \mathrm{p}<.05, * * \mathrm{p}<.01, * * * \mathrm{p}<.001$.

\section{Contraceptive use}

Compared to fertility desire, contraceptive use revealed a considerably greater susceptibility to influence from gender power variables. Wife's power emerged significantly related to contraceptive use in all samples, except urban Indonesia 
under Model I and rural India under Model II. Wife's power and husband's beliefs were independently related to contraceptive use in five samples. Husband's beliefs unrelated to wife's power alone in rural India and wife's power unrelated to husband's beliefs alone in rural Ethiopia were the exceptions. Fertility desire and oversampling exhibited nearly universal and strong impacts, whereas number of living children (not shown) presented little impact and did not modify the pattern of relationships.

TABLE 3. Adjusted exponential coefficients from the logistic regression of wife's contraceptive use on husband's normative or residual beliefs, wife's HDM or residual power, wife's plus husband's fertility desire, and oversampling, per predictor set, model, and sample.

\begin{tabular}{|c|c|c|c|c|c|c|c|c|c|c|c|c|}
\hline \multirow{2}{*}{\multicolumn{2}{|c|}{ Samples }} & \multirow[b]{2}{*}{ Model } & \multicolumn{4}{|c|}{$\underline{\text { Predictor Set } 1}$} & \multicolumn{6}{|c|}{$\underline{\text { Predictor Set II }}$} \\
\hline & & & $\begin{array}{c}\mathrm{H} \\
\text { Beliefs }\end{array}$ & $\begin{array}{c}\text { W } \\
\text { Power }\end{array}$ & $\begin{array}{l}\mathrm{W}+\mathrm{H} \\
\text { Desire }\end{array}$ & $\begin{array}{c}\text { Over- } \\
\text { sampling }\end{array}$ & $\mathrm{N}$ & $\begin{array}{l}\text { H Res. } \\
\text { Beliefs }\end{array}$ & $\begin{array}{l}\text { W Res. } \\
\text { Power }\end{array}$ & $\begin{array}{l}\mathrm{W}+\mathrm{H} \\
\text { Desire }\end{array}$ & $\begin{array}{c}\text { Over- } \\
\text { sampling }\end{array}$ & $\mathrm{N}$ \\
\hline India & Rural & I & $1.04 * *$ & $1.07 * * *$ & $0.53 * * *$ & $0.64 * * *$ & 8,416 & 1.01 & $1.04 * *$ & $0.53 * * *$ & $0.65^{* * *}$ & 8,416 \\
\hline Indonesia & Urban & II & $1.06 * * *$ & 1.02 & $0.52 * * *$ & $0.38 * * *$ & 8,272 & 1.02 & $1.04 * *$ & $0.53 * * *$ & $0.64 * * *$ & 8,268 \\
\hline Nigeria & Rural & I & $1.08 * *$ & $1.12 * * *$ & $0.54 * * *$ & $0.55^{* * *}$ & 8,125 & $1.05^{*}$ & $1.08 * * *$ & $0.54 * * *$ & $0.56^{* * *}$ & 8,125 \\
\hline \multirow[t]{11}{*}{ Ethiopia } & Urban & II & $1.08^{*}$ & $1.08^{* * *}$ & $0.54 * * *$ & $0.40 * * *$ & 7,993 & 1.01 & $1.08 * * *$ & $0.54 * * *$ & $0.56^{* * *}$ & 7,991 \\
\hline & Rural & I & $1.27 * * *$ & $1.09 * * *$ & $0.81 * * *$ & $0.79 * *$ & 3,798 & $1.17 * * *$ & $1.06^{*}$ & $0.81 * * *$ & $0.79^{* *}$ & 3,795 \\
\hline & Urban & II & $1.14 * * *$ & $1.06^{*}$ & $0.84 * * *$ & $0.78 * * *$ & 3,704 & $1.13^{* * *}$ & $1.06^{*}$ & $0.814 * * *$ & $0.79^{* *}$ & 3,695 \\
\hline & Rural & I & 1.03 & 1.02 & $0.69 * * *$ & 1.17 & 2,557 & 1.07 & 1.03 & $0.68 * * *$ & 1.18 & 2,557 \\
\hline & & II & & $1.07^{*}$ & $0.73^{* * *}$ & $1.19^{*}$ & 2,496 & & 1.04 & $0.67 * * *$ & 1.20 & 2,494 \\
\hline & & I & & $1.25^{* * *}$ & $0.53^{* * *}$ & $0.55^{* * *}$ & 4,945 & & $1.07 * * *$ & $0.48 * * *$ & $0.55^{* * *}$ & 4,941 \\
\hline & & II & & $1.22 * * *$ & $0.55^{* * *}$ & $0.53 * * *$ & 4,885 & & $1.06^{*}$ & $0.48 * * *$ & $0.59 * * *$ & 4,880 \\
\hline & & I & & $1.20 * * *$ & $0.58 * * *$ & $0.49 * * *$ & 1,838 & & $1.09 * * *$ & $0.56^{* * *}$ & $0.46^{* * *}$ & 1,837 \\
\hline & & II & & $1.17 * * *$ & $0.61 * * *$ & $0.43 * * *$ & 1,823 & & $1.08 * *$ & $0.56^{* * *}$ & $0.51 * * *$ & 1,820 \\
\hline & & I & & $1.10^{*}$ & $0.62 * * *$ & $0.62 * *$ & 1,772 & & 1.06 & $0.62 * * *$ & $0.59^{* *}$ & 1,772 \\
\hline & & II & & $1.07+$ & $0.64 * * *$ & $0.63^{*}$ & 1,744 & & 1.04 & $0.62 * * *$ & $0.60^{* *}$ & 1,744 \\
\hline
\end{tabular}

Removal of age/education/work covariance implied a loss of significance for wife's power in urban Indonesia and rural Ethiopia under Model I, while no change was registered under Model II. Husband's beliefs lost significance in urban Indonesia under Model II. Figure 3, comparing the size of the average Model II odds-ratios,

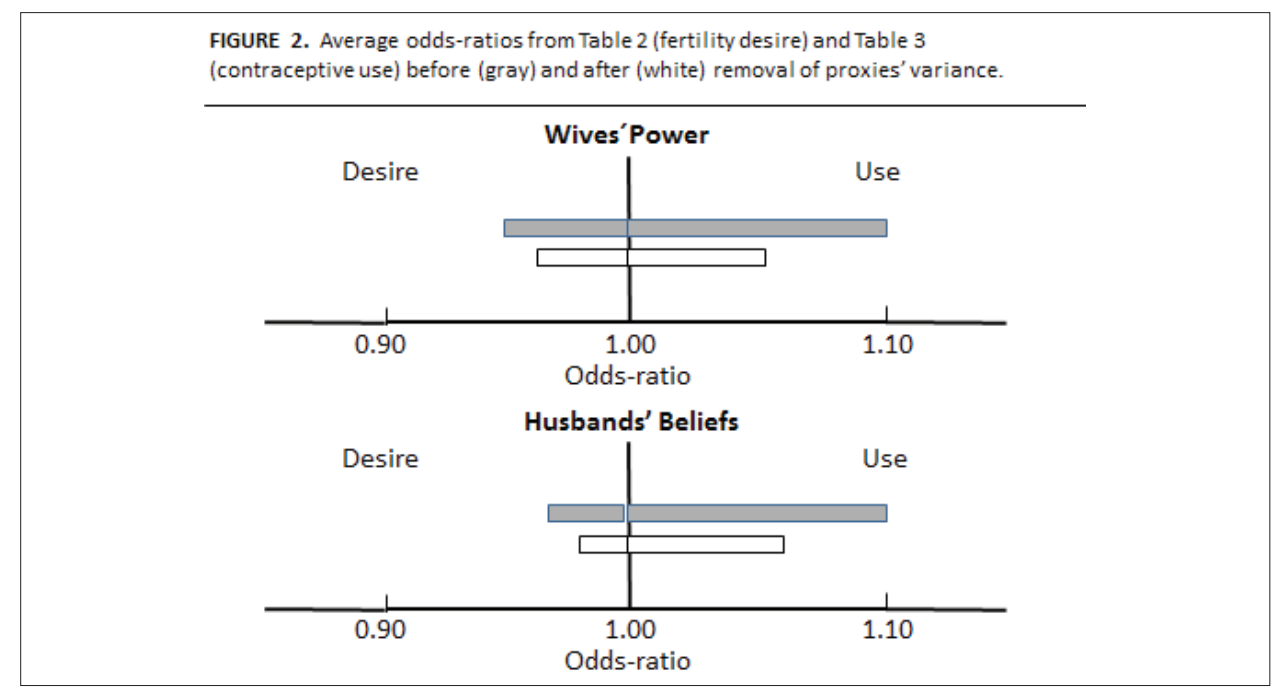


EFECTOS INDEPENDIENTES DEL PODER DOMÉSTICO DE LA ESPOSA Y LOS VALORES IGUALITARIOS DEL CÓNYUGE...

shows that the effects of wife's HDM power and husband's normative beliefs on wife's fertility desire and contraceptive use shrink but hardly disappear after proxies' variance removal. The losses amounted to less than 50 per cent in all cases and little differences were seen between power and beliefs in this regard.

\section{DISCUSSION}

The first question addressed in this study was whether men's normative beliefs and women's power are redundant as determinants of family planning behaviour or both can influence contraceptive use with independence from each other. The study results clearly showed that wife's power and husband's beliefs, in general, are far from being redundant, for both simultaneously determined contraceptive use in a majority of settings: rural and urban areas of Indonesia and Nigeria and urban areas of India. Only two exceptions were found under Model II: husband's egalitarian beliefs unrelated to wife's power alone determined contraceptive use in rural India and wife's HDM power unrelated to husband's beliefs alone did in rural Ethiopia. Additionally, wife's power which could be associated with husband's beliefs (Model I) was related to contraceptive use in all settings, except urban Indonesia. Up to now, researchers and programs have thought only of women's HDM power and husband's normative beliefs and have generally addressed these concepts without regard for their possible joint effects on reproductive behaviour. The results of the present research strongly suggest the convenience of differentiating effects of gender power variables on contraceptive use which stem from three sources: wife power associated with husband's beliefs, wife power which is independent of husband's beliefs, and husband's beliefs which are independent of wife's power. This not only is theoretically transcendent but also has practical implications. By being oblivious to the differentiation of the three types of effects, program interventions may be targeting power constructs which are too diffuse to respond to the programmatic objectives. By ignoring that women's power and men's beliefs may independently influence contraceptive use, programs are not taking advantage of the opportunity to enhance the impact of their gender empowerment interventions via the incorporation of an additional source of effects. The study findings strongly suggest that gender empowerment interventions to improve contraceptive use could be importantly strengthened if they targeted couples rather than women or men alone.

The second question pertained to the differentiation of gender power variables' effects on contraceptive use and met need for contraception; specifically, the extent to which women's power and men's beliefs influence fertility desire. The latter makes the difference between contraceptive use and met need in the Simplest Framework. The study findings indicated that independent effects of wife's power and husband's beliefs on wife's fertility desire are infrequent; they were found only in urban India. Furthermore, whereas wife's power and husband's beliefs independently determined contraceptive use in either urban or rural settings, this was not the case of fertility desire: wife's power reduced wife's fertility desire 
in most of the rural areas (the exception was Indonesia) while husband's beliefs did in the three urban settings studied. Rural societies are known to contain more remnants of the patriarchal family organization than urban societies, including men's greater desire for children. The findings of this study were consistent with these realities, for they revealed a greater desire for children in rural than urban settings in the four countries encompassed and among men than women in three of them, the exception being India (see Table 1). Women may need greater power to dare to desire delaying or stopping fertility in rural than urban settings. Men's individual degree of egalitarianism in rural settings may not be enough to weaken the effects on women of the social forces favouring large families. Men's egalitarianism may become more functional in this respect in urban settings, where women's power may lose relevance. On the other hand, once the wife has decided to delay or stop fertility, both her power and her husband's egalitarianism appear to become instrumental to the adoption of contraception regardless of setting. This can be understood considering that freedom of movement and control of economic resources facilitate access to family planning in urban as well as in rural areas. Research on the relationship between gender power and contraceptive use which does not pay attention to need for contraception ignores these nuances and may become useless. What must be promoted is research which focuses on met need for contraception or implements the Simplest Framework.

The third topic of the article referred to the nature of the gender-power constructs. The study findings showed that, like women's power, husband's normative beliefs conforming to the egalitarian power model adopted in the research explained contraceptive use in nearly all settings. A second question was whether a core men's normative beliefs would continue to influence fertility desire and contraceptive use after removal of beliefs' covariance with age, education, and work, as was known to be the case of women's power. The study findings showed a parallel shrinkage of women's power and men's beliefs. In both cases, the reduction in explanatory power amounted to less than 50 per cent of the odds-ratios. What could underlie this independent core? The independent women's power core has been attributed to a personality trait: assertiveness (León 2012). But perhaps a more important question regarding the internal structure of the constructs pertains to the nature of the new entities that emerged in this study: a husband's egalitarianism which is independent from wife's power and a wife's power which is independent of husband's egalitarianism. One way of making inroads into the meaning of these entities is asking about what makes husbands different from wives. A relevant finding in this respect may have been the difference that was observed in the internal consistency of the power and beliefs measures. If a woman showed a given level of power to decide on visits to relatives, she was also likely to exhibit the same amount of power to make large purchases for the home or purchases for daily needs. This, however, was less so in the realm of husbands' beliefs. That is, the occurrence of inconsistencies across domestic areas was more likely to occur among husbands' beliefs' than in wives' self-reported power. Husbands expressed a more differentiated view of the domestic areas, whereas wives tended to report 
either submission across the board, a middle level of power across the board, or a high power level across the board. More thought and research along these lines is needed to better understand the emerging constructs. More reliable research tools must be developed. Although the finding of consistent relationships on the basis of three or four questionnaire items speaks of robust phenomena, the development of stronger scales would help to make finer distinctions. This endeavour should also consider that questionnaire items may not have exactly the same meaning across countries (Ghuman, Lee, \& Smith 2006).

On the other hand, possible semantic differences in the questionnaires seem unlikely causes of the international differences observed in the study findings. With respect to impacts on fertility desire, for example, similar differences were seen between linguistically homogeneous urban and rural areas within the same country (e.g., Nigeria) as between linguistically heterogeneous countries (e.g., urban Nigeria versus urban Indonesia). Nonetheless, some particularities were noticeable. Only in the rural settings of Nigeria and Ethiopia the effects of wife's power on fertility desire remained significant after removal of age/education/work covariance. This was also the case for the effects of husband's beliefs on contraceptive use in rural and urban Nigeria. A better understanding of the situational contingencies that moderate the relationships between power and beliefs with fertility desire and contraceptive use is certainly needed.

\section{REFERENCES}

Al Riyami, A., Afifi, M., \& Mabry, R.M. (2004) Women's autonomy, education, and employment in Oman and their influence on contraceptive use. Reproductive Health Matters, 12, 144-154.

Bankole, A. (1995) Desired fertility and fertility behavior among the Yoruba of Nigeria: A study of couple preferences and subsequent fertility. Population Studies, 49, 317-328.

Bankole, A. \& Singh, S. (1998) Couples' fertility and contraceptive decision-making in developing countries: Hearing the man's voice. International Family Planning Perspectives, 24, 15-24.

Becker, S. (1996) Couples and reproductive health: A review of couple studies. Studies in Family Planning, 27, 291-306.

Biddlecom, A., Casterline, J. B., \& Pérez, A. E. (1996) Men's and women's views of contraception. Policy Research Division Working Paper No. 92. New York: Population Council.

Biddlecom, A. \& Fapohunda, B. M. (1998) Covert contraceptive use: prevalence, motivations, and consequences. Studies in Family Planning, 29, 360-372.

Blanc, A. K. (2001) The effect of power in sexual relationships on sexual and reproductive health: An examination of the evidence. Studies in Family Planning, 32, 189-213. 
Blanc, A. K. \& Wolff, B. (2001) Gender and decision-making over condom use in two districts in Uganda. African Journal of Reproductive Health, 5, 15-28.

Bongaarts, J. \& Bruce, J. 1995. The causes of unmet need for contraception and the social content of services. Studies in Family Planning, 26, 57-75.

Casique, I. (2003) Uso de anticonceptivos en México: ¿Qué diferencia hacen el poder de decisión y la autonomía femenina? Papeles de Población, 35, 209-233.

Casterline, J. B., Pérez, A. E., \& Biddlecom, A. E. (1997) Factors underlying unmet need for family planning in the Philippines. Studies in Family Planning, 28, 173-191.

Castle, S., Kane Kunaté, M., Ulin, P. R., \& Martin, S. (1999) A qualitative study of clandestine contraceptive use in urban Mali. Studies in Family Planning, 30, 231-248.

Chavoshi, M. H,, Abbasi-Shavazi, M. J., \& McDonald, P. (2004) Women's autonomy and reproductive behavior in Iran. Biennial Conference of the Australian Population Conference. Camberra.

Courtenay, W. H. (2000) Constructions of masculinity and their influence on men's wellbeing: a theory of gender and health. Social Science \& Medicine, 50, 1385-1401.

DeRose, L. F., Dodoo, F. N-A., \& Patil, V. (2002) Fertility desires and perceptions of power in reproductive conflict in Ghana. Gender \& Society, 16, 53-73.

DeRose, L. F., \& Ezeh, A. C. (2010) Decision-making patterns and contraceptive use: evidence from Uganda. Population Research and Policy Review, 29, 423-439.

DeRose, L. F., Wu, L., \& Dodoo, F. N-A. (2010) Inferring gender power: women's schooling and relative spousal influence in childbearing in Ghana. Genus, 66, 69-91.

Do, M \& Kurimoto, N. (2012) Women's empowerment and choice of contraceptive methods in selected African countries. International Perspectives on Sexuality and Reproductive Health, 38, 23-33.

Dodoo, F. N-A. (1998) Men matter: additive and interactive gendered preferences and reproductive behavior in Kenya. Demography, 35, 229-242.

Ezeh, A. C. (1993) The influence of spouses over each other's contraceptive attitudes in Ghana. Studies in Family Planning, 24, 163-174.

Faiella, I. (2010) The use of survey weights in regression analysis. Working Paper No. 739. Rome: Banca d'Italia.

Feldman, B. S, Zaslavsky, A. M., Ezzati, M., Peterson, K. E., \& Mitchell, M. (2009) Contrceptive use, birth spacing, and autonomy: an analysis of the Oportunidades program in rural Mexico. Studies in Family Planning, 40, 51-62.

Gebreselassie, T. \& Mishra, V. (2011) Spousal agreement on preferred waiting time to next birth in Sub-Saharan Africa. Journal of Biosocial Science, 43, 385-400.

Gelman, A. (2007) Struggles with survey weighting and regression modelling. Statistical Science, 22, 153-164. 
EFECTOS INDEPENDIENTES DEL PODER DOMÉSTICO DE LA ESPOSA Y LOS VALORES IGUALITARIOS DEL CÓNYUGE...

Ghana Statistical Service, Ghana Health Service, \& ICF Macro (2009) Ghana Demographic and Health Survey 2008. Accra, Ghana, Author.

Ghuman, S. J., Lee, H. J., \& Smith, H. L. (2006) Measurement of women's autonomy according to women and their husbands: Results from five Asian countries. Social Science Research, 35, 1-28.

Govindasamy, P. \& Malhotra, A. (1996) Women's position and family planning in Egypt. Studies in Family Planning, 27, 328-340.

Green, M. E. \& Biddlecom, A. E. (2000). Demographic accounts of male reproductive roles. Population and Development Review, 26, 81-115.

Gupta, G. R. \& Weiss. E. (1993). Women's lives and sex: Implications for AIDS prevention. Medicine and Psychiatry, 17, 399-412.

Hashemi, S. M., Schuler, S. R., Riley, A. P. (1996) Rural credit programs and women's empowerment in Bangladesh. World Development, 24, 635-653.

Hogan, D. P, Berhanu, B., \& Hailemariam, A. (1999) Household organization, women's autonomy, and contraceptive behavior in southern Ethiopia. Studies in Family Planning, $30,302-314$.

Institut de Statistiques et d'Études Économiques du Burundi et al. (2012) Enquete Demographique et de Santé Burundi 2010. Bujumbura, Burundi, Authors.

Instituto Nacional de Estadística, Ministerio de Salud y Deportes, et al. (2009). Encuesta Nacional de Demografía y Salud 2008. La Paz, Bolivia, Authors.

Jejeebhoy, S. J. (2002) Convergence and divergence in spouses' perspectives on women's autonomy in rural India. Studies in Family Planning, 33, 299-308.

Kimuna, S. R. \& Adamchak, D. J. (2001) Gender relations: Husband-wife fertility and family planning decisions in Kenya. Journal of Biosocial Science, 33, 13-23.

Kishor, S. \& Gupta, K. (2009) Gender equality and women's empowertment in India. New Dehli: International Institute for Population Sciences.

Kishor, S. \& Subaiya, L. (2008) Understanding women's empowerment: A comparative analysis of Demographic and Health Surveys (DHS) data. DHS Comparative Studies No. 20.

Kulczycki, A. (2008) Husband-wife agreement, power relations and contraceptive use in Turkey. International Family Planning Perspectives, 34, 127-137.

Lee-Rife, S. M. (2010) Women's empowerment and reproductive experiences over the lifecourse. Social Science \& Medicine, 71, 634-642.

León, F. R. (2011) Does professed religion moderate the relationship between women's domestic power and contraceptive use in India? The Open Family Studies Journal, $4,1-8$. 
León, F. R. (2012) Predicting contraceptive use from an egalitarian model of women's overall household power vis-à-vis conventional power models and third variables. Journal of Biosocial Science, DOI 10.1017/

S0021932012000624.

León, F. R., Lundgren, R., Sinai, I.,, \& Jennings, V. (2011) The role of need for contraception in the evaluation of interventions to improve access to family-planning methods. Evaluation Review, 35, 3-13.

Mahalik, J. R., Locke, B. D., Scott, R. P. J., Gottfried, M., \& Freitas, G. (2003) Development of the Conformity to Masculine Norms Inventory. Psychology of Men \& Masculinity, 4, 3-25.

Malhotra, A., Schuler, S. R., \& Boender, C. (2002) Measuring women's empowerment as a variable in international development. World Bank's Social Development Group.

Mason, K. O. \& Smith, H. L. (2000) Husbands' versus wives' fertility goals and use of contraception: the influence of gender context in five Asian countries. Demography 37, 299-311.

Moursund, A. \& Kravdal, O. (2003) Individual and community effects of women's education and autonomy on contraceptive use in India. Population Studies, 57, 285-301.

Mumtaz, Z., Slaymaker, E., \& Salway, S. (2005) Condom use in Uganda and Zimbabwe: exploring the influence of gendered access to resources and couple-level dynamics. In Kishor, S. (ed.), A focus on gender: collected papers using DHS data. ORC Macro.

National Population Commission \& ICF Macro (2009) Nigeria Demographic and Health Survey 2008. Abuja, Nigeria, Author.

Ngom, P. (1997) Men's unmet need for family planning: Implications for African fertility transitions. Studies in Family Planning, 28, 192-202.

Peacock, D. \&Levack, A. (2004) The Men as Partners Project in South Africa: reaching men to end gender-based violence and promote sexual and reproductive health. International Journal of Men's Health, 3, 173-188.

Piet-Pelon, N., Rob, U., \& Khan, M. E. (1999) Men in Bangladesh, India and Pakistan: reproductive health issues. Dhaka: Karshaf Publishers.

Pulerwitz, J. \& Barker, G. (2008) Measuring attitudes toward gender norms among young men in Brazil. Men and Masculinities, 10, 322-338.

Pulerwitz, J. \& Dworkin, S. L. (2006) Give-and-take in safer sex negotiations: the fluidity of gender-based power relations. Sexuality Research \& Social Policy, 3, 40-51.

Pulerwitz, J., Micahelis, A., Verman, R., \& Weiss, E. (2010) Addressing gender dynamics and engaging men in HIV programs: lessons learned from Horizons research. Public Health Reports, 125, 282-292. 
EFECTOS INDEPENDIENTES DEL PODER DOMÉSTICO DE LA ESPOSA Y LOS VALORES IGUALITARIOS DEL CÓNYUGE...

Roy, T. K. \& Niranjan, S. (2004) Indicators of women's empowerment in India. AsiaPacific Population Journal, 19, 23-40.

Rutenberg, N. \& CottsWatkins, S. (1997) The buzz outside the clinics: conversations and contraception in Nyanza Province, Kenya. Studies in Family Planning, 28, 290-307.

Rutstein, S. O., \& Rojas, G. (2006) Guide to DHS statistics. Calverton, MD: Demographic and Health Surveys/ORC Macro.

Saleem, S. \& Bobak, M. (2005) Women's autonomy, education and contraception use in Pakistan: a national study. Reproductive Health, 2.

Sathar, Z., Callum, C., \& Jejeebhoy, S. (2001) Gender, region, religion and reproductive behaviour in India and Pakistan. IUSSP, XXIV General Population Conference. Salvador, Brazil.

Schuler, S. R., Hashemi, S. M., \& Riley, A. P. (1997) The influence of changing rules and status in Bangladesh's fertility transition. Evidence from a study of credit programs and contraceptive use. World Development, 25, 563-575.

Seguino, S. (2007) Plus Ca Change? Evidence on global trends in gender norms and stereotypes. Feminist Economics, 13, 1-28.

Shattuck D, Kerner B, Gilles K, Hartmann M, Ng'ombe T,, \& Guest, G. (2011). Encouraging contraceptive uptake by motivating men to communicate about family planning: the Malawi Male Motivator Project. American Journal of Public Health, 101, 1089-1095.

Singh, A. \& Becker, S. (2012) Concordance between partners in desired waiting time to birth for newlyweds in India. Journal of Biosocial Science, 44, 57-71.

Speizer, I. S., Whittle, S., \& Carter, M. (2005) Gender relations and reproductive decisionmaking in Honduras. International Family Planning Perspectives, 31, 131-139.

Steele, F., Amin, S., \& Naved, R. T. (2001) Saving/credit group formation and change in contraception. Demography, 38, 267-282.

Upadhyay, U. D. \& Karasek, D. (2012) Women's empowerment and ideal family size: an examination of DHS empowerment measures in sub-Saharan Africa. International Perspectives in Sexual and Reproductive Health, 38, 78-89.

United Nations Development Programme (2012) Human Development Report. New York, Author.

Verma, R. K., Pulerwitz, J., Mahendra, V. S., Khandekar, S., Singh, A. K., Das, S. A., Nura, A., \& Barker, G. (2008) Promoting gender equity as a strategy to reduce HIV risk and gender-based violence among young men in India. Horizons Final Report. Washington, D.C.: Population Council.

Woldemicael, G. (2009) Women's autonomy and reproductive preferences in Eritrea. Journal of Biosocial Science, 41, 161-181. 
Wolff, B., Blanc, A. K., \& Ssekamatte-Ssebuliba, J. (2000) The role of couple negotiation in unmet need for contraception and the decision to stop childbearing in Uganda. Studies in Family Planning, 31, 124-137.

\section{ACKNOWLEDGEMENTS}

The research presented in this article was sponsored by the C-Change program funded by the United States Agency for International Development. The views expressed, however, do not necessarily reflect the views or policies of USAID, AED, or FHI360. The author is grateful to Jim Foreit, Sara Woldehanna, Gloria Coe, Susan Middlestadt, Geeta Nanda, and Susan Zimicki for their help in various aspects of the research and to Sid Schuler for comments that improved the manuscript. Thanks are extended to Demographic and Health Surveys for allowing access to DHS data sets. 